\title{
Learning Modes and Preferences of MAPEH Students: Basis for Designing Learning and Instructional Materials (LIMs)
}

\author{
${ }^{1}$ Sarah Urabang, ${ }^{2}$ Anabelie V. Valdez \\ MSU Balindong Community High School
}

\begin{abstract}
This study aimed to assess the learning modes and learning preferences of students in learning Music, Arts, Physical Education and Health (MAPEH). Research design used was descriptive-correlational involving 120 grade 10 students of Mindanao State University, Balindong Community High School for the school year 2018-2019. Survey questionnaires were used in data gathering and the data were analyzed statistically using SPSS software. Findings revealed that the learning mode of the students varies same with their learning preferences. They also prefer more than one learning modes and learning preference depending on the learning situation and tasks they performed. Furthermore, the results of the study revealed that learning mode and learning preference has direct relationship and significantly related at 0.01 level of significance. Thus, the researchers proposed different models for designing learning and instructional materials to be used or patterned by the teachers in teaching in order to cater the individual or group learners learning mode, learning preference and individual differences.
\end{abstract}

Keywords: learning mode, learning preference, learning materials, instructional materials

\section{INTRODUCTION}

Improving the academic performance of the students is a major concern of all teachers and educators alike. Study conducted by Yusof et al. (2017) revealed that teacher skills such as planning, managing and knowledge in curriculum have direct effect on student learning. Similarly study of Ibrahim and Amin (2017) concluded that teacher's effectiveness in teaching directly affect students achievement. Educators, policy makers focus on identifying teacher quality and curriculum reform but there were only few attention has been given to the learners' ability to learn particularly about their learning mode and preferences. It is very important to an educator to evaluate students' learning mode and learning preferences so that they will be able to match it to their teaching styles and develop an Instructional Materials (IMs) accordingly.

Learning preferences and styles varies from learners to learners. Valdez's (2018) research findings on the congruency of teachers' teaching styles and students' learning styles concluded that learning is meaningful, participative and exciting if the teachers' teaching approaches matches to the learners' learning styles. Similarly, Kara's (2009) findings pointed out that a mismatch of students' learning styles and teachers' teaching styles is not favourable to an effective learning process. Students' learning become more difficult resulting to their poor performance (Peakock, 2001).

Several studies had been conducted about the importance of learning styles and teaching styles congruency suggested that teachers should assess first the learning styles of their students and try to accommodate the individual differences of the learners to their teaching methods and instructional materials use in class. According to Tulbure (2012), teaching strategies and learning style is significantly related and the flexibility, creativity and responsibility of meeting the different learning styles of the learners are on the hands of the teachers. Knowing the learning styles of the learners as a basis for teaching has impacts to the teachers and the learners (Kharb, Samanta, Jindal, \& Singh (2013). This study is anchored from the research findings and suggestions of researchers regarding the importance of determining the learning styles of the learners. The objective of this study is to look into the learning mode and learning preferences of grade 10 students in Music, Arts, Physical Education and Health (MAPEH). Specifically answering the following questions;

(C) 2019, IJSMS 
1. What is the common learning mode of students in MAPEH?

2. What are the common learning preferences of students in MAPEH?

3. Is there significant mean difference between learning mode, learning preference and sex of the respondents?

4. Is there a relationship between learning mode, learning preference, and sex of the respondents?

5. What are the possible instructional materials to be developed to match the learning mode and learning preferences of students?

Findings of this study serve as the basis of the teachers in designing their instructional materials and preparing their teaching methodologies.

\section{METHODOLOGY}

\subsection{Research Design}

This study made use of survey research design using a survey questionnaire. Surveys research design provides meaningful data in determining the learning mode and learning preferences of the respondents. In this method, the respondents answered the given close-ended questionnaires.

\subsection{Research Respondents}

The respondents of the study were the grade 10 Music, Arts, Physical Education and Health (MAPEH) students of MSU-Balindong Community High School year 2018-2019. MAPAEH is considered as one core subject in the Philippines junior high school curriculum. It is a one subject combining four areas which is Music, Arts, Physical Education and Health. A total of 120 grade 10 students in MAPEH were taken purposively as the respondents of the study. They were selected as respondents since they were mature enough to handle their learning abilities and they were moving forward to senior high. Their responses could be a good source of information in designing instructional materials and teaching strategies among educators more specifically in MSU-Balindong Community High School.

Table 1. Frequency and Percentage Distribution of Respondents according to Sex

\begin{tabular}{|l|c|c|}
\hline Sex & Frequency & Percent \\
\hline male & 46 & 38.3 \\
\hline female & 74 & 61.7 \\
\hline Total & 120 & 100 \\
\hline
\end{tabular}

\subsection{Instruments}

This study used self-learning style inventory questionnaires adapted from Learning Style Survey (LSS): Assessing Your Own Learning Styles by Cohen and Oxford, (2001). The survey questionnaire consists of 11 parts. Each part has corresponding statement to represent 23 different aspects of learning styles. For each item were rated by a scale of 0 never; 1 rarely; 2 sometimes; 3 often; and 4 always. The LSS was tested in terms of its validity and reliability with Cronbach's alphas of .89 (M. OnurCesurSevalFer, 2009).

Another questionnaire was also given to evaluate students learning mode to gives idea on how students learn. This questionnaire was pattern from the idea of Kolb (1984) and Felder-Silverman Learning Style Model. This questionnaire determined the learning mode of the respondents according to the four stage of learning cycle. This questionnaire is a Learning style inventories on how students learn by ranking order the set of four works in each item. There are ten items in total consisting of four set of works. In this questionnaire the respondents will assign number 4 to the word which best characterizes his/her learning mode, a 3 to the next best, a 2 to the next, and a 1 to the least characteristic word. These questionnaires were validated in Philippine setting to ensure content appropriateness to the Filipino respondents. 
Table 2. Set of works to determine the learning modes of the respondents in learning MAPEH

\begin{tabular}{|c|c|c|c|c|}
\hline No. & Column 1 & Column 2 & Column 3 & Column 4 \\
\hline 1. & involved & tentative & discriminating & practical \\
\hline 2. & receptive & impartial & analytical & relevant \\
\hline 3. & feeling & watching & thinking & doing \\
\hline 4. & accepting & aware & evaluating & risk-taker \\
\hline 5. & intuitive & questioning & logical & productive \\
\hline 6. & concrete & observing & abstract & active \\
\hline 7. & present-oriented & reflecting & future-oriented & practical \\
\hline 8. & $\begin{array}{l}\text { open to new } \\
\text { experience }\end{array}$ & perceptive & intelligent & competent \\
\hline 9. & experience & observation & conceptualization & experimentation \\
\hline 10. & intense & reserve & rational & responsible \\
\hline total & $\begin{array}{l}\text { Concrete } \\
\text { Experience }\end{array}$ & $\begin{array}{l}\text { Reflective } \\
\text { Observation }\end{array}$ & $\begin{array}{l}\text { Abstract } \\
\text { Conceptualization }\end{array}$ & $\begin{array}{l}\text { Active } \\
\text { Experimentation }\end{array}$ \\
\hline
\end{tabular}

\subsection{Data Gathering Procedure}

The data of this study was gathered through survey using survey questionnaires and naturalistic observation. The gathered data were summarized according to characteristics of learning mode and preferences of the respondents. Survey was done to obtained useful information needed in the study. Naturalistic observation was done through observations of students' behaviour in class activities in order to triangulate the information gathered from the survey questionnaire. There is no time limit of the respondents in answering the survey questionnaire for them to internalize the situation as they experienced. The questionnaire was given to them in the morning and allowing them to bring it home and then submitted it any time as they finished answering the questions. The researcher retrieved all the questionnaires for around one (1) week period.

\subsection{Data Analysis}

The gathered data were analysed statistically through Statistical Package of Social Sciences (SPSS).Descriptive statistics such as frequency, mean, and standard deviation were used in describing the learning mode and learning preferences of the respondents. Analysis of variance was used to determine the significant different on the mean between learning mode, learning preference and sex of the respondents. Relationship between learning mode and learning preference was also measured using Pearson Product of correlation. Quantitative and qualitative descriptions were used in the interpretation and discussions of the gathered data.

\section{FINDINGS AND DISCUSSIONS}

\subsection{Students Learning Mode}

Students learning mode was assessed using learning style inventory. The inventory gives idea on how students will learn. It does not evaluate students learning ability. In the inventory there were ten items containing 4 set of works and the respondents numbered it from 1 to 4 , in which 4 is the highest. From the obtained data, the number of each column in Table 2 was added and the highest score represents the most preferred learning mode of the respondents. Figure 1 below shows the most preferred learning mode of the respondents. 
Volume: 2 Issue: 4

July to August 2019

www.ijsmsjournal.org

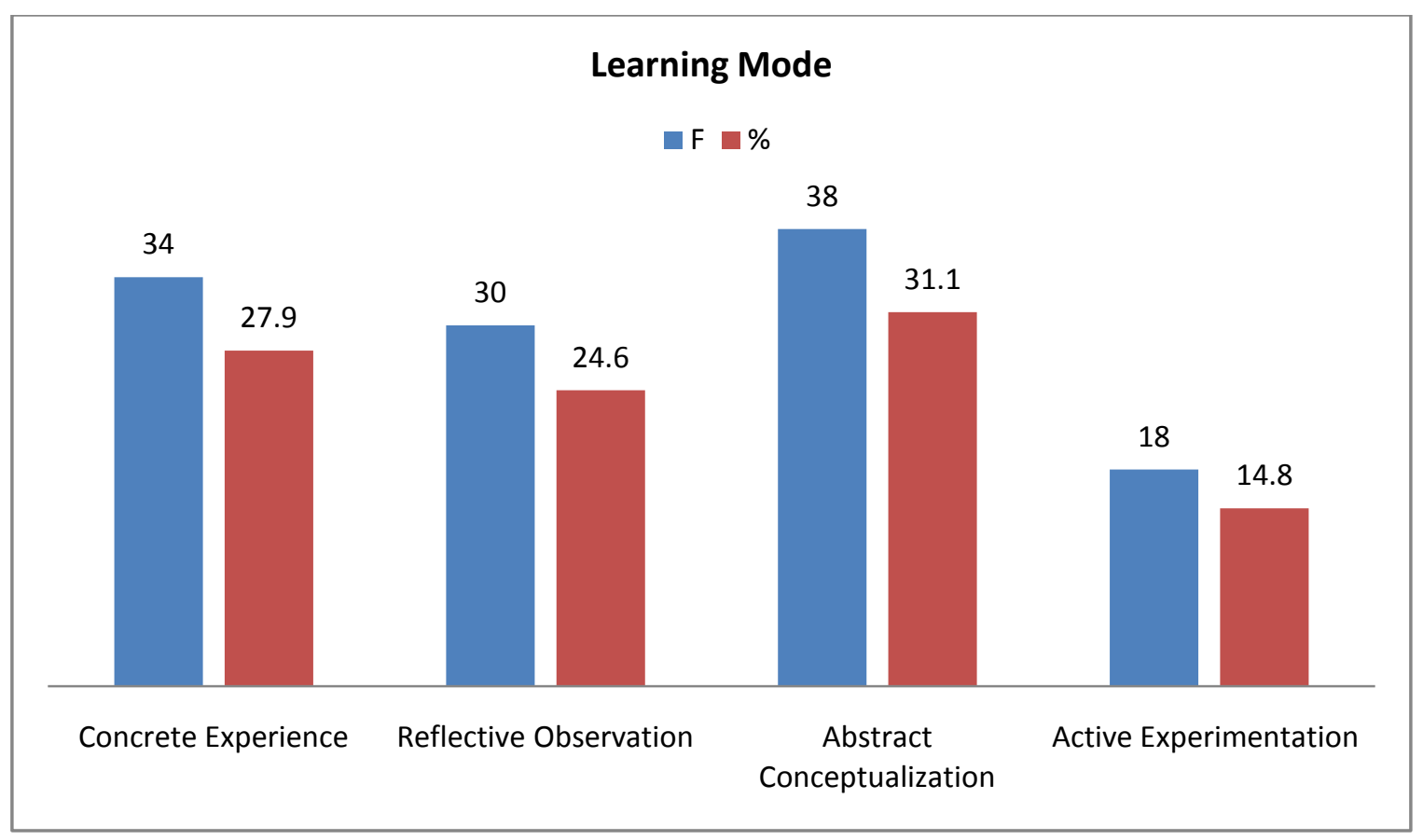

Mean $=1.333 \quad$ Std. Deviation $=1.049$

Figure 1- Students Learning Mode

Figure 1 displays the preferred learning modes of the students. As shown in the figure abstract conceptualization obtained a highest frequency/percentage, followed by concrete experience and reflective observation. Active experimentation is the least learning mode of the MAPEH students.

The result implies that many MAPEH students are more incline to abstract conceptualization. They prefer to learn in a form of concluding or learning from experience. They can learn better using logic, ideas and concepts. The students usually use their thinking skills rather than feelings, more concern on theories and specific things.

The second group of students like concrete experience. This means that this kind of students learn better through experiencing things, doing or having experience. They loved to be involved in experiences and apply it personally in human situations. They are more after of the feeling than thinking, more concern on uniqueness and complexity. They love artistic approach and intuition.

The third group of students learn better through reflective observation. They wanted to focus on understanding the meaning and situations through careful observations. They are good on reflection on how things happen and how it will work. They wanted to review and reflect their experiences.

The fourth and the last group of students can learn better through active experimentation. They wanted to engage on practical activities. This kind of students prefers to learn through careful planning and trying out what they have learned. They can learn fast if they will perform.

\subsection{Students Learning Preferences}

Students learning preferences were assessed using learning style inventory adapted from Andrew D. Cohen, Rebecca L. Oxford, and Julie C. Chi (2006). The set of questions does not predict students' behaviour in every instance; instead it will indicate the overall style preferences of the learners. There were 11 major activities representing 12 different aspects of students learning style. The respondents marked the questionnaire using the following scale: 0 - never; 1-rarely; 2- sometimes; 3 - often; and 4 -always. The answered of the respondents was 
then totalled in table form (see Table 3). Once the points are totalled, frequency, percentage, means, and standard deviation was computed (see Table 4).

Table 3. Tabulation table for students learning preferences

\begin{tabular}{|l|l|l|}
\hline Part1: & Part5: & Part9: \\
AVisual & AGlobal & AField-Independent \\
BAuditory & BField-Dependent \\
C Tactile/Kinesthetic & BParticular & \\
\hline Part2: & & Part10: \\
AExtroverted & Part6: & AImpulsive \\
BIntroverted & ASynthesizing & BReflective \\
\hline Part3: & BAnalytic & Part11: \\
ARandom-Intuitive & Part7: & BLetaphoric \\
BConcrete-Sequential & ASharpener & \\
\hline Part4: & BLeveler & \\
AClosure-Oriented & Part8: & \\
BOpen & ADeductive & \\
& BInductive & \\
\hline
\end{tabular}

Table 4. Learning Preferences of Grade 10 MAPEH Students

\begin{tabular}{|c|c|c|c|c|c|c|}
\hline \multicolumn{3}{|c|}{ Learning Preferences } & Frequency & $\%$ & Mean & Std. Deviation \\
\hline \multirow[t]{3}{*}{ I. } & \multirow{3}{*}{ Using Physical Senses (UPS) } & Visual & 58 & 48.33 & \multirow{3}{*}{.7750} & \multirow{3}{*}{.83477} \\
\hline & & Auditory & 31 & 25.83 & & \\
\hline & & Tactile/Kinesthetic & 31 & 25.83 & & \\
\hline \multirow[t]{2}{*}{ II. } & \multirow{2}{*}{$\begin{array}{l}\text { When Expose to Learning Situation } \\
\text { (ELS) }\end{array}$} & Extroverted & 45 & 37.5 & \multirow[t]{2}{*}{.6250} & \multirow[t]{2}{*}{.48615} \\
\hline & & Introverted & 75 & 62.5 & & \\
\hline \multirow[t]{2}{*}{ III. } & \multirow[t]{2}{*}{ Handling Possibilities (HP } & Random Intuitive & 57 & 47.5 & \multirow[t]{2}{*}{.5250} & \multirow[t]{2}{*}{.50147} \\
\hline & & Concrete Sequential & 63 & 52.5 & & \\
\hline \multirow[t]{2}{*}{ IV. } & \multirow{2}{*}{$\begin{array}{l}\text { Dealing with Ambiguity and with } \\
\text { Deadlines (DAD) }\end{array}$} & Closure Oriented & 81 & 67.5 & \multirow[t]{2}{*}{.3250} & \multirow[t]{2}{*}{.47034} \\
\hline & & Open & 39 & 32.5 & & \\
\hline \multirow[t]{2}{*}{ V. } & \multirow[t]{2}{*}{ Receiving Information (RI) } & Global & 35 & 29.17 & \multirow[t]{2}{*}{.7083} & \multirow[t]{2}{*}{.45644} \\
\hline & & Particular & 85 & 70.83 & & \\
\hline \multirow[t]{2}{*}{ VI. } & \multirow[t]{2}{*}{ Processing Information (PI) } & Synthesizing & 64 & 53.33 & \multirow[t]{2}{*}{.4667} & \multirow[t]{2}{*}{.50098} \\
\hline & & Analytic & 56 & 46.67 & & \\
\hline \multirow[t]{2}{*}{ VII. } & \multirow{2}{*}{$\begin{array}{l}\text { Integrating Material to Memory } \\
\text { (IMM) }\end{array}$} & Sharpener & 61 & 50.83 & \multirow[t]{2}{*}{.4917} & \multirow[t]{2}{*}{.50203} \\
\hline & & Leveler & 59 & 49.17 & & \\
\hline \multirow[t]{2}{*}{ VIII. } & \multirow{2}{*}{$\begin{array}{l}\text { Dealing with Language Rule } \\
\text { (DLR) }\end{array}$} & Deductive & 47 & 39.17 & \multirow[t]{2}{*}{.6083} & \multirow[t]{2}{*}{.49017} \\
\hline & & Inductive & 73 & 60.83 & & \\
\hline \multirow[t]{2}{*}{ IX. } & Dealing with Multiple Inputs & Field Independent & 61 & 50.83 & .4917 & .50203 \\
\hline & $(\mathrm{DMI})$ & Field Dependent & 59 & 49.17 & & \\
\hline $\mathrm{X}$. & Dealing with Response Time & Impulsive & 58 & 48.33 & .5167 & .50182 \\
\hline & $(\mathrm{DRT})$ & Reflective & 62 & 51.67 & & \\
\hline XI. & Taking the Reality (TR) & Metaphoric & 63 & 52.5 & .4750 & .50147 \\
\hline & & Literal & 57 & 47.5 & & \\
\hline
\end{tabular}

As shown in the table, in terms of using the physical senses many (48.33\%) students prefer to use their visual senses in learning. This means that the students rely mostly on their sense of sight and can easily learn when the learning and teaching approach are more on visual means like video, charts, pictures and reading books. These 
findings are similar to the research findings of Shaaidi (2012) that most students preferred visual learning style over the other styles. The researcher also recommend that teachers should know better of the preferred learning styles of the students so that they can be able to prepare teaching approaches and instructional materials that will match the learning styles of the students.

There were only few (25.83\%) prefer to learn using auditory and kinaesthetic. Students who prefer auditory learn easily through listening and speaking activities such as discussions, lectures, audiotapes and role plays, while students who prefer kinaesthetic/tactile can learn easily through practical works such as experimentations, games, and making models. They love hands-on approach.

In terms of exposing to learning situations, majority (62.5\%) of the students prefer of being introverted. This means that they wanted to learn and work independently. On the other hand few $(37.5 \%)$ of them prefer extroverted. These students prefer to handle a learning situation through interactive learning tasks like games, dialogue, role plays, debates, simulations, etc.).

In handling possibilities many (52.5\%) students favour of being concrete sequential. They are more present oriented and handle the possibilities one step at a time activities. They are also cognizant of their learning every moment. While the other (47.5\%) who favour on random intuitive, they are more on future oriented in terms of handling possibilities. They enjoy abstract thinking and speculate all possibilities what can be or what it is.

In dealing with ambiguity and deadlines, many (67.5\%) are closure oriented. This kind of students will focus carefully on learning tasks and strive to meet deadlines. They have the ability to plan ahead and wanted to have explicit directions. The students $(32.5 \%)$ who favour to be open orientation in dealing ambiguity and deadlines are more adventurous. They enjoy discovery learning and more relax without concerning the deadlines to meet.

In terms of receiving information majority $(70.83 \%)$ of the students prefer to be very particular. They wanted to focus on details and always concern on specific information. Students $(29.17 \%)$ who prefer to be global in receiving information tend to enjoy of getting the gist or substance and are very comfortable in communicating particularly in knowing new words or concepts from different sources.

In processing information, many (53.33\%) students want synthesizing approach. This kind of students has ability to summarize the lessons or concepts very well. They also enjoy of guessing meanings, predicting outcomes and similarities. Other students (46.67\%) prefer to be analytic in processing further the information. They can pull ideas apart and they are good on logical analysis. They are good in critical thinking.

In the aspect of integrating material or concepts to memory, $50.83 \%$ of the students are sharpener, while $49.17 \%$ are leveller. Students that have sharpener ability in integrating concepts to memory can easily detect differences and distinctions. They tend to separate memories from memories and can easily retrieve of those. On the other hand, leveller students wanted to clump material or concepts together for them to be remembered easily and to reduce the differences. Sharpener ability is good when it concern to accuracy while leveller is good on expediency and they good in communicating and speaking.

MAPEH students also deal language rules in different manner. There are $60.83 \%$ of them preferring inductive approach and $39.17 \%$ prefer deductive method. Students that are inductive learner learn better from specific to general approach and prefer to begin the discussions with examples than theories or concepts. While students who prefer deductive method they learn well on general to specific approach. They wanted to start the lessons on rules and theories or by applying generalizations to experiences.

MAPEH students vary in terms of dealing with multiple inputs. Some (50.83\%) are field independent and $49.17 \%$ are field dependent. Students who favour on field independent method will like to separate abstract things from a given context and in any distractions, while students who are field dependent will deal information in holistic manner and can work best without distractions. 
In terms of dealing the response of time MAPEH students deal it impulsively and reflectively. As shown in Table 2, there are $51.67 \%$ students who can deal with response to time in a reflective manner. These students will think and reflect first before taking their response. Other students $(48.33 \%)$ will deal it impulsively. They react speedily without rationalizing the situation of problem.

Lastly, in terms of the MAPEH students literally take the reality, 52.5\% prefer to be metaphoric in nature while $51.67 \%$ prefer to be reflective. Students who prefer metaphoric are learners that can learn concepts easily. They are good in comprehension and able to develop and apply metaphor. While students who prefer reflective style is learners that need literal representation of the concepts being taught to them.

Generally, out of eleven (11) learning preferences using physical senses (mean $=0.775$ ) is the learning preference commonly preferred by the MAPEH students while dealing with ambiguity and deadline is the least (mean $=0.3250)$ preferred by the MAPEH students in learning.

\subsection{Relationship between Learning Modes, Learning Preferences and Sex of the Respondents}

Table 5. Analysis of variance between learning modes and learning preferences of respondents

\begin{tabular}{|c|c|c|c|c|c|c|}
\hline \multicolumn{2}{|l|}{ Learning Mode \& Learning Preferences } & $\begin{array}{l}\text { Sum of } \\
\text { Squares }\end{array}$ & If & $\begin{array}{l}\text { Mean } \\
\text { Square }\end{array}$ & $\mathrm{F}$ & Sig. \\
\hline \multirow[t]{3}{*}{ 1. Using Physical Senses (UPS) } & Between Groups & 69.572 & 3 & 23.191 & 201.468 & .000 \\
\hline & Within Groups & 13.353 & 116 & .115 & & \\
\hline & Total & 82.925 & 119 & & & \\
\hline \multirow{3}{*}{$\begin{array}{l}\text { 2. When Expose to Learning } \\
\text { Situation (ELS) }\end{array}$} & Between Groups & 21.158 & 3 & 7.053 & 117.434 & .000 \\
\hline & Within Groups & 6.967 & 116 & .060 & & \\
\hline & Total & 28.125 & 119 & & & \\
\hline \multirow[t]{3}{*}{ 3. Handling Possibilities (HP } & Between Groups & 24.558 & 3 & 8.186 & 176.942 & .000 \\
\hline & Within Groups & 5.367 & 116 & .046 & & \\
\hline & Total & 29.925 & 119 & & & \\
\hline \multirow{3}{*}{$\begin{array}{l}\text { 4. Dealing with Ambiguity and } \\
\text { with Deadlines (DAD) }\end{array}$} & Between Groups & 16.930 & 3 & 5.643 & 69.681 & .000 \\
\hline & Within Groups & 9.395 & 116 & .081 & & \\
\hline & Total & 26.325 & 119 & & & \\
\hline \multirow[t]{3}{*}{ 5. Receiving Information (RI) } & Between Groups & 23.825 & 3 & 7.942 & 953.000 & .000 \\
\hline & Within Groups & .967 & 116 & .008 & & \\
\hline & Total & 24.792 & 119 & & & \\
\hline \multirow[t]{3}{*}{ 6. Processing Information (PI) } & Between Groups & 29.867 & 3 & 9.956 & & \\
\hline & Within Groups & .000 & 116 & .000 & & \\
\hline & Total & 29.867 & 119 & & & \\
\hline \multirow{3}{*}{$\begin{array}{ll}\text { 7. Integrating Material to Memory } \\
\text { (IMM) }\end{array}$} & Between Groups & 27.292 & 3 & 9.097 & 390.844 & .000 \\
\hline & Within Groups & 2.700 & 116 & .023 & & \\
\hline & Total & 29.992 & 119 & & & \\
\hline \multirow{3}{*}{$\begin{array}{ll}\text { 8. Dealing with Language Rule } \\
\text { (DLR) }\end{array}$} & Between Groups & 21.225 & 3 & 7.075 & 111.407 & .000 \\
\hline & Within Groups & 7.367 & 116 & .064 & & \\
\hline & Total & 28.592 & 119 & & & \\
\hline \multirow{3}{*}{$\begin{array}{l}\text { 9. Dealing with Multiple Inputs } \\
\text { (DMI) }\end{array}$} & Between Groups & 27.292 & 3 & 9.097 & 390.844 & .000 \\
\hline & Within Groups & 2.700 & 116 & .023 & & \\
\hline & Total & 29.992 & 119 & & & \\
\hline \multirow{3}{*}{$\begin{array}{l}\text { 10. Dealing with Response Time } \\
\text { (DRT) }\end{array}$} & Between Groups & 25.167 & 3 & 8.389 & 202.731 & .000 \\
\hline & Within Groups & 4.800 & 116 & .041 & & \\
\hline & Total & 29.967 & 119 & & & \\
\hline \multirow[t]{3}{*}{ 11. Taking the Reality (TR) } & Between Groups & 28.958 & 3 & 9.653 & $1.158 \mathrm{E} 3$ & .000 \\
\hline & Within Groups & .967 & 116 & .008 & & \\
\hline & Total & 29.925 & 119 & & & \\
\hline
\end{tabular}


Table 5a Analysis of variance between learning modes and sex of respondents

\begin{tabular}{|l|r|r|r|r|r|}
\hline \multicolumn{2}{|l|}{ Learning mode and sex } & & & & \\
\hline & Sum of Squares & df & Mean Square & \multicolumn{1}{c|}{ F } & \multicolumn{1}{c|}{ Sig. } \\
\hline Between Groups & 85.797 & 1 & 85.797 & 225.633 & .000 \\
\hline Within Groups & 44.870 & 118 & .380 & & \\
\hline Total & 130.667 & 119 & & & \\
\hline
\end{tabular}

Table 5b Analysis of variance between learning preferences and sex of respondents

\begin{tabular}{|c|c|c|c|c|c|c|}
\hline \multicolumn{2}{|l|}{ Learning Preferences and Sex } & $\begin{array}{c}\text { Sum of } \\
\text { Squares }\end{array}$ & $\mathrm{df}$ & $\begin{array}{c}\text { Mean } \\
\text { Square }\end{array}$ & $\mathrm{F}$ & Sig. \\
\hline \multirow{3}{*}{$\begin{array}{l}\text { 1. Using Physical Senses } \\
\text { (UPS) }\end{array}$} & Between Groups & 44.803 & 1 & 44.803 & 138.682 & .000 \\
\hline & Within Groups & 38.122 & 118 & .323 & & \\
\hline & Total & 82.925 & 119 & & & \\
\hline \multirow{3}{*}{$\begin{array}{ll}\text { 2. } & \text { When Expose to Learning } \\
& \text { Situation (ELS) }\end{array}$} & Between Groups & 27.147 & 1 & 27.147 & $3.274 \mathrm{E} 3$ & .000 \\
\hline & Within Groups & .978 & 118 & .008 & & \\
\hline & Total & 28.125 & 119 & & & \\
\hline \multirow{3}{*}{$\begin{array}{l}\text { 3. Handling Possibilities } \\
\text { (HP }\end{array}$} & Between Groups & 20.560 & 1 & 20.560 & 259.064 & .000 \\
\hline & Within Groups & 9.365 & 118 & .079 & & \\
\hline & Total & 29.925 & 119 & & & \\
\hline \multirow{3}{*}{$\begin{array}{l}\text { 4. Dealing with Ambiguity } \\
\text { and with Deadlines } \\
\text { (DAD) }\end{array}$} & Between Groups & 7.879 & 1 & 7.879 & 50.403 & .000 \\
\hline & Within Groups & 18.446 & 118 & .156 & & \\
\hline & Total & 26.325 & 119 & & & \\
\hline \multirow{3}{*}{$\begin{array}{ll}5 . & \text { Receiving Information } \\
& (\mathrm{RI})\end{array}$} & Between Groups & 16.422 & 1 & 16.422 & 231.530 & .000 \\
\hline & Within Groups & 8.370 & 118 & .071 & & \\
\hline & Total & 24.792 & 119 & & & \\
\hline \multirow{3}{*}{$\begin{array}{ll}6 . & \text { Processing Information } \\
& (\mathrm{PI})\end{array}$} & Between Groups & 16.245 & 1 & 16.245 & 140.726 & .000 \\
\hline & Within Groups & 13.622 & 118 & .115 & & \\
\hline & Total & 29.867 & 119 & & & \\
\hline \multirow{3}{*}{$\begin{array}{l}\text { 7. Integrating Material to } \\
\text { Memory (IMM) }\end{array}$} & Between Groups & 18.032 & 1 & 18.032 & 177.918 & .000 \\
\hline & Within Groups & 11.959 & 118 & .101 & & \\
\hline & Total & 29.992 & 119 & & & \\
\hline \multirow{3}{*}{$\begin{array}{ll}\text { 8. } & \text { Dealing with Language } \\
& \text { Rule (DLR) }\end{array}$} & Between Groups & 27.605 & 1 & 27.605 & $3.302 \mathrm{E} 3$ & .000 \\
\hline & Within Groups & .986 & 118 & .008 & & \\
\hline & Total & 28.592 & 119 & & & \\
\hline \multirow{3}{*}{$\begin{array}{ll}9 . & \text { Dealing with Multiple } \\
\text { Inputs (DMI) }\end{array}$} & Between Groups & 18.032 & 1 & 18.032 & 177.918 & .000 \\
\hline & Within Groups & 11.959 & 118 & .101 & & \\
\hline & Total & 29.992 & 119 & & & \\
\hline \multirow{3}{*}{$\begin{array}{l}\text { 10. Dealing with Response } \\
\text { Time (DRT) }\end{array}$} & Between Groups & 19.913 & 1 & 19.913 & 233.706 & .000 \\
\hline & Within Groups & 10.054 & 118 & .085 & & \\
\hline & Total & 29.967 & 119 & & & \\
\hline \multirow[t]{3}{*}{ 11. Taking the Reality (TR) } & Between Groups & 16.830 & 1 & 16.830 & 151.665 & .000 \\
\hline & Within Groups & 13.095 & 118 & .111 & & \\
\hline & Total & 29.925 & 119 & & & \\
\hline
\end{tabular}

Table 5, 5a, and 5b present the results of the analysis of variance between learning mode, learning preferences and sex of the respondents. Analysis of variance was used to determine the significant difference of the mean between variables. As shown in the tables, the mean difference between learning modes and learning preferences, learning modes and sex, and learning preferences and sex significantly differ. This result implies that the respondents learning mode, learning preferences significantly differ with respect to their sex. According to Kolb learning theory a person or learners' preferred learning style are influence by many factors such as sex, social environment, educational experiences and cognitive structure. Learning is dependent on learners processing 
continuum and perception continuum. It is a responsibility of the teachers to evaluate critically the learning preferences of the students for the teachers to develop appropriate learning opportunities. Arp \& Woodard (2006) as cited by Gülbahar\&Alper (2011), every learner learn in his own way since there no single preferred learning style that works for all learners.

Table 5.c Correlation between learning mode, learning preferences and sex of respondents

\begin{tabular}{|c|c|c|c|c|c|c|c|c|c|c|c|c|c|}
\hline & \multicolumn{11}{|c|}{ Learning Preferences } & \multirow[t]{2}{*}{ Sex } \\
\hline & & UPS & ELS & HP & DAD & RI & PI & IMM & DLR & DMI & DRT & TR & \\
\hline \multirow[t]{2}{*}{ Mode } & $\mathrm{r}$ & $.884^{* *}$ & $.808^{* *}$ & $.848^{* *}$ & $.750^{* *}$ & $.802^{* *}$ & $.886^{* *}$ & $.868^{* *}$ & $.813^{* *}$ & $.868^{* *}$ & $.852^{* *}$ & $.880^{* *}$ & $.810^{* *}$ \\
\hline & $\begin{array}{l}\text { Sig. (2- } \\
\text { tailed) }\end{array}$ & .000 & .000 & .000 & .000 & .000 & .000 & .000 & .000 & .000 & .000 & .000 & .000 \\
\hline \multirow[t]{3}{*}{ Sex } & $\mathrm{r}$ & $.735^{* *}$ & $.982^{* *}$ & $.829^{* *}$ & $.547^{* *}$ & $.814^{* *}$ & $.738^{* *}$ & $.775^{* *}$ & $.983^{* *}$ & $.775^{* *}$ & $.815^{* *}$ & $.750^{* *}$ & \\
\hline & $\begin{array}{l}\text { Sig. (2- } \\
\text { tailed) }\end{array}$ & .000 & .000 & .000 & .000 & .000 & .000 & .000 & .000 & .000 & .000 & .000 & \\
\hline & $\mathrm{N}$ & 120 & 120 & 120 & 120 & 120 & 120 & 120 & 120 & 120 & 120 & 120 & 120 \\
\hline
\end{tabular}

As shown in Table 5.c all of the eleven learning preferences of grade 10 MAPEH students are positively and significantly correlated to their learning mode and sex. Recalling data in Figure 1, four (4) learning mode of the grade 10 MAPEH students are evident namely and according to rank; 1) abstract conceptualization; 2) concrete experience; 3 ) reflective observation; and 4) active experimentation respectively. These learning modes significantly influence to the learning preferences of the students and vice versa.

Different studies have shown various relationships of learning preferences, learning mode, learning styles and teaching styles. Study of Önen (2015) about the connections between modes of thinking and learning approaches revealed that revealed that there is a positive relationship between thinking and the learning approaches. Gülbahar and Alper (2011) concluded in their study about learning preferences and learning styles of online adult learners that teaching approaches and instructional materials should match the learning preferences and learning styles of the students in order to maximize the teaching-learning process and the learning outputs. The study conducted by Rezaeinejada, Azizifara and Gowharya (2015) about students learning styles and academic achievement found out that there is a significant relationship between learning styles and academic achievement of students. Moreover, their findings also showed that the effect of learning styles to the academic performance of the students will vary according to the type of subject and grade level.

\subsection{Proposed Model for Designing Learning and Instructional Materials (LIMs)}

Table 3. Suggested learning and instructional materials that cater the different learning styles of the learners

\begin{tabular}{|c|c|c|c|}
\hline Learning Material & $\begin{array}{c}\text { Suggested Instructional } \\
\text { Approach }\end{array}$ & $\begin{array}{c}\text { Learning } \\
\begin{array}{c}\text { Style/Preference to } \\
\text { be Addressed }\end{array} \\
\end{array}$ & Learning Mode \\
\hline \multirow[t]{2}{*}{$\begin{array}{l}\text { 1. Module on In-Class Activities for } \\
\text { individualized learning with } \\
\text { differentiated activities (e.g. problem } \\
\text { solving worksheet, storytelling, case } \\
\text { studies, books, newspaper) }\end{array}$} & $\begin{array}{l}\text { project-based learning/ } \\
\text { instruction, individualized } \\
\text { instruction, independent } \\
\text { study, case-based }\end{array}$ & $\begin{array}{l}\text { individual/ } \\
\text { solitary learning }\end{array}$ & $\begin{array}{l}\text { self-study/ } \\
\text { independent study, } \\
\text { anytime learning, } \\
\text { concrete experience }\end{array}$ \\
\hline & $\begin{array}{l}\text { activity-based instruction, } \\
\text { direct instruction, } \\
\text { instructional game }\end{array}$ & $\begin{array}{l}\text { social/collaborative } \\
\text { learning }\end{array}$ & $\begin{array}{l}\text { group work, live } \\
\text { training, multimedia } \\
\text { learning, active }\end{array}$ \\
\hline
\end{tabular}


Interactive Learning Environment with contextualized and differentiated activities (e.g. activity-based worksheet/module, real-life experiences, brainstorming, real-life critical analysis, role playing

3. Self-Learning Kit (SLK) Module with differentiated and contextualized activities (e.g. story books, audio news casting, model construction, games, student writing, manipulative)

4. Comic Strip Learning (CSL) Module with differentiated and contextualized activities (e.g. multimedia instructional materials (modules, graphics, video, webquest, printed materials like module, books, graphs, puzzles, newspaper etc.)

\begin{tabular}{|l|l|l|}
\hline $\begin{array}{l}\text { direct instruction, case } \\
\text { study, storytelling, lecture }\end{array}$ & auditory learning & $\begin{array}{l}\text { participation } \\
\text { listening, audio learning, } \\
\text { reflective listening and } \\
\text { observation }\end{array}$ \\
\hline $\begin{array}{l}\text { demonstration and } \\
\text { presentation, instructional } \\
\text { simulation, }\end{array}$ & visual learning & $\begin{array}{l}\text { watching, e-learning, } \\
\text { multimedia learning, } \\
\text { abstract } \\
\text { conceptualization }\end{array}$ \\
\hline $\begin{array}{l}\text { discovery approach, } \\
\text { problem-based approach, } \\
\text { experimenting approach }\end{array}$ & concrete learning & $\begin{array}{l}\text { hands-on, experiential, } \\
\text { discovering, live } \\
\text { training, active } \\
\text { experimentation and } \\
\text { concrete experience }\end{array}$ \\
\hline $\begin{array}{l}\text { direct instruction, inquiry- } \\
\text { based approach }\end{array}$ & abstract learning & $\begin{array}{l}\text { reading, anytime } \\
\text { learning, abstract } \\
\text { conceptualization }\end{array}$ \\
\hline $\begin{array}{l}\text { linear instruction, inquiry- } \\
\text { based approach }\end{array}$ & logical learning & $\begin{array}{l}\text { thinking, anytime } \\
\text { learning, abstract } \\
\text { conceptualization }\end{array}$ \\
\hline $\begin{array}{l}\text { direct instruction, drill and } \\
\text { practice, inquiry-based } \\
\text { approach }\end{array}$ & sensual learning & $\begin{array}{l}\text { feeling, hands-on, } \\
\text { experiential, anytime } \\
\text { learning, concrete } \\
\text { experience }\end{array}$ \\
\hline
\end{tabular}

\section{CONCLUSION AND RECOMMENDATION}

Based on the results of the study every learner has its own learning mode and preference. Every style preference bids substantial strengths among learners in doing their learning tasks. Identifying the learners' mode and learning preferences is necessary in designing learning and instructional materials so as to cater the different learning styles, multiple intelligences and pace of the learners. It is interesting to note in the findings that learning mode and learning preference are significantly correlated. Therefore, the study concluded that any learning and instructional materials should be designed in accordance to the learning mode and learning preferences of the learners. Furthermore, teachers should determine first the learning mode and learning preference of the learners prior to designing learning materials. To accommodate learners' individual differences and interest, learning and instructional materials should be designed in a differentiated and contextualized approach. As Nzesei (2015) said, contextual and cultural sensitivity teaching plays larger role in learning compared to learning styles same as true with the use of differentiated instructions. Thus, the proposed model in designing learning and instructional materials presented in this study is very timely and relevance and this should be used or pattern by all educators.

\section{References}

[1] Arp, L. \& Woodard, B. S. Accommodating Diverse Learning Styles in an Online Environment. Reference \& User Services Quarterly, 2006;46(2):27-32.

[2] Gulbahar, Y. andAlper, A. (2011). Learning Preferences and Learning Styles of Online Adult Learners. ResearchGate, https://www.researchgate.net/publication/266592841

[3] CESUR, M. O. \& FER, S. (2009). What Is Validity And Reliability Study Of Learning Style Survey? Egitimde Kuramve Uygulama 2009,5 (2):289-315, Journal of Theory and Practice in Education Articles /Makaleler ISSN: 1304-9496 http://eku.comu.edu.tr/index/5/2/mocesur_sfer.pdf

[4] Cohen, A.D. \& Oxford, R. (2001). Learning Style Survey: Assessing Your Own Learning Styles Learning Style Survey*: Assessing Your Own Learning Styles A -Total https://www.researchgate.net/publication/266356106

[5] Cohen, A. D., Oxford, R. L., \& Chi, J. C. (2001).Learning style survey.Online: http//carla.acad.umn.edu/profiles/Cohen-profile.html.

[6] Ibrahim, M. Y \& Amin, A. (2017). Model kepemimpinanpengajaranpengetuadankompetensi pengajaran guru. JuKu: JurnalKurikulum\&Pengajaran Asia Pasifik, 2(1): 11-25. 
[7] Kara, S. (2009). Learning Styles and Teaching Styles: A Case Study in Foreign Language Classroom. Conference ofthe International Journal Of Arts And Sciences 1(20): 77 - 82 (2009) Cd-Rom. Issn: 1943-6114 @ Internationaljournal.Org Anadolu University, Turkey.

[8] Kharb,KSamanta,P.P.; Jindal,M. and Singh, V. (2013). The Learning Styles andthe Preferred Teaching—Learning Strategies of First Year Medical Students. Published Online 2013 Apr 22. DOI: 10.7860/Jcdr/2013/5809.3090Pmcid: Pmc3708205

[9] Nzesei, M. (2015). A Correlation Study between Learning Styles And Academic Achievement Among Secondary School Students in Kenya, University Of Nairobi

[10] Önen, E. (2015). Connections between Modes of Thinking and Learning Approaches:Implications for Education and Research. Journal of Education and Learning; Vol. 4, No. 1; 2015 ISSN 1927-5250 E-ISSN 1927-5269 Published by Canadian Center of Science and Education.

[11] Peacock, M. (2001). Match Or Mismatch? Learning Styles and Teaching Styles inEFL. International Journal of Applied Linguistics, 11(1), $1-20$.

[12] Reid, J. M. (1987). The Learning Style Preferences ofESL Students.TESOL Quarterly, 21(1), 87-111.

[13] Rezaeinejad, M.; Azizifar, A. and Gowhary, H. (2015). The Study of Learning Styles and Its Relationship with Educational Achievement among Iranian High School Students. GlobELT: An International Conference on Teaching and Learning English as an Additional Language, Antalya - Turkey Published by Elsevier Ltd.

[14] Shaaidi, W.R.W. (2012). A Study of the Preferred Learning Styles of Students taking the English 1119 Paper in SMK TengkuIntanZaharah: Are the Teachers aware of these Learning Styles? ResearchGate. DOI 10.13140/RG.2.13212403

[15] Tulbure, C. (2012). Learning Styles, Teaching Strategies andAcademic Achievement In Higher Education: A Cross-Sectional Investigation.Procedia - Social and Behavioral Sciences 33 (2012) 398 - 4021877-0428.Published By Elsevier B.V. Selection and/or PeerReview under Responsibility of Psiworld2011Doi:10.1016/J.Sbspro.2012.01.151

[16] Valdez, A. V. (2018). Congruency of Teachers Teaching Style (TS), and Students Learning Style (LS) In Mindanao State University (MSU) Balindong Community High School: An Assessment. International Journal of Education Humanities and Social Science Vol. 1, No. 02

[17] Yusof, M. R. B., Ibrahim. M. Y. \& Rahim, S.B. A. (2017). Virtual Instructional Leadership and Teachers' Teaching Competency: Mediated by Communication Pattern. International Journal of Academic Research in Business and Social Sciences, 7(8): 96-108. 